\title{
ANALYSIS OF \\ BALANCE SCORECARDS MODEL PERFORMANCE AND PERSPECTIVE STRATEGY SYNERGIZED BY SEM
}

\author{
Minto Waluyo $^{1}$, Syamsul Huda ${ }^{1}$, Noer Soetjipto ${ }^{2}$, Sumiati ${ }^{1 .}$, Handoyo ${ }^{1}$ \\ ${ }^{1}$ University of Pembangunan Nasional "Veteran" Jawa Timur, Surabaya, East Java, Indonesia, \\ 2. University Muhammadiyah Gresik. \\ Email: mintowaluyo_ti@yahoo.co.id, syamsulhuda-prof10@yahoo.co.id, \\ noersoetjipto@yahoo.co.id, busumiati_tic@yahoo.com, handoyo_ti@yahoo.com
}

\begin{abstract}
The performance assessment analysis after the economic crisis by using Balanced Scorecard (BSC) method becomes a powerful and effective tool and can provide an integrated view of the performance of an organization. This strategy led to the Indonesian economy being stretched positively after the economic crisis. Taking effective decisions is not spared from combining four BSC perspectives and strategies that focus on a system with different behavior or steps. This paper combines two methods of BSC with structural equation modeling (SEM)) because they have the same concept, which is a causal relationship, where the research model concept SEM variables use BSC variable. The purpose of this paper is to investigate the influence of variables that synergized between balanced scorecard with SEM as a means of strategic planning in the future. This study used primary data with a large enough sample to meet the maximum likelihood estimation by assessment scale of seven semantic points. This research model is a combination of one and two step models. The next step is to test the measurement model, structural equation modeling, and modification models. The test results indicated that the model has multi colinearities. Therefore, the model is converted into one step model. The test results after being modified into a model of the goodness of fit indices showed a good score. All BSC variables have direct significant influence, including the perspective of strategic goals and sustainable competitive advantage. The implication of the simulation model of goodness of fit-modification results are $\mathrm{DF}=227$, Chi-square $=276.550, \mathrm{P}=0.058, \mathrm{CMIN} / \mathrm{DF}=$ $1.150, \mathrm{GFI}=0.831, \mathrm{AGFI}=0.791, \mathrm{CFI}=0.972, \mathrm{TLI}=0.965$ and $\mathrm{RMSEA}=0.039$.
\end{abstract}

Keywords: balanced scorecard variable, perspective of strategic objectives, SEM, center of small enterprises

\section{INTRODUCTION}

The monetary crisis in 1997-1998 has made a number of foreign observers predict that Indonesia would be scattered as such in Europe, which after years was repeatedly hit by the economic crisis. However, Indonesia is stronger that it did not take long to be able to crawl up and come out of the crisis. The lower level of the economy at that time, such as the traditional markets, minimarkets, and even supermarkets were still running well. SMEs were still running well because they do not use the capital facility of bank loans, but this can not be allowed because it would cause SMEs become unable to capture a greater opportunity. The Government of Indonesia has provided a policy where major employers have to live with the aid of liquid funds from Bank of Indonesia to bridge SMEs and the national economy so that they become more exist. The direct impact of the monetary crisis hit large businesses whose capital came from bank loans.

One example of the performance of SMEs discussed in this paper is the field of slippers and furniture industries, in which the further research is on the evaluation of balanced scorecards for small and medium enterprises (SMEs), and the continuation of a previous research on Sustainable Competitive Advantage $\left(\mathrm{X}_{5}\right)$ entitled "Analysis on Performance Model Using Balanced Score Card, Strategic Objective and Sustainable Competitive Advantage Synergized with SEM."

This strategy has made the economy react positively. This effective decision included combining four perspective steps of BSC that focused on a system with different behaviors. (Kaplan \& Norton, 1996b) created the BSC method with the concept of causality so that researchers having BSC mindset can be synergized with SEM, using large enough data to support it (Baggio and Sainaghi, 2011). The previous research has suggested that customers and financial performance are causally related to each other (Nielsen, et al, 2012). BSC is applied to the marketing of a comprehensive performance management to demonstrate the relationship between the marketing performance measurement system and the performance of the company as a condition of marketing alignment and knowledge-based market (Taylor and Baines, 2012).

The advantage of BSC is due to the balance between financial and non-financial variables, move his problems focus on financial variables, customer and business process / internal focus on the future of learning and growth variables (Banker et al, 2004). The year of 2004 was a crucial moment, which the election in Indonesia that ran peacefully became the energy to drive the wheels of the economy to move faster. The achievement of the Indonesian leaders within a decade was able to maintain the high level of economic growth in the range of $4-6 \%$. It is only China and India that could reach that level. However, in terms of stability of economic growth, Indonesia is number one in worldwide. Indonesian leaders in the decade of 2004-2014 were the pioneers of stability post the economic crisis, and the Indonesian leaders in the decade of 2014-2019 are expected to be able to maintain and improve the programs to become more positive, realistic, accountable, and credible. Although Indonesia was struggling at the beginning of its administration, but it has high flight hours tips executed confidently to overcome the problem, besides having the spirit and motivation plus prayers by the people of Indonesia. 


\section{THEORETICAL AND BACKGROUND CENTER OF SMALL ENTERPRISES}

The center of SME is a small area that has certain characters where production process exists and it is a more specific area for economic activity commodity that has been formed naturally and supported by facilities in order to develop the products or services. It consists of micro, small, and middle-level entrepreneurs. There is a physical union of functions in the center land, geography, infrastructure, institutions, and human resources that have potentials in developing the economy activity under the market influence of a product with higher selling point and competitiveness. This theory of matter has been discussed in the paper entitled The evaluation of balanced scorecards for small and medium enterprises, with eight and nine hypotheses for this study.

\section{Balanced Scorecard (BSC).}

According to (Johnson and Kaplan, 1987), in the need for better performance measurement system, BSC is a flexible performance measurement method that can be used for measuring the performance of the enterprise or institution which consists of four perspectives: financial, customer, internal business processes, learning and growth (Kaplan \& Norton, 1996a).

This study became different because the learning and growth variables are made into separate variables, in addition to researchers who led Strategic Objective variable as a variable of the ultimate goal supported by a strong theory. BSC can define long-term strategic objectives of each perspective (outcomes) and mechanisms to achieve these objectives (performance driver). This approach combines long-term strategic objectives due to the impact of short-term events. The four processes translate the vision, mission and strategy of the company in determining the size of the performance. The organization's vision is outlined in goals and objectives (Kaplan and Norton, 1996a).

The objective was then explained in the strategic objectives along with the measurement of its achievement. The manager is able to make better decisions by using four perspectives of BSC (Lipe dan Salterio, 2000). The empirical research of BSC combines different steps: financial and operational, qualitative and quantitative (Ittner at. al, 1998; Dess dan Shaw, 2001). Sangjae at, al. (2013) synergizes BSC with PLS by using data from 101 companies to examine the causal relationship between the four categories of BSC. Zahirul Hoque (2014) reported a paper which synergizes BSC with partial least squares (PLS) using limited primary data to examine the causal relationship between the four categories of BSC. Tobia (1999) posited that PLS is useful in screening out negligible factors affecting the dependent variable.

The research framework can be seen in figure 1 and the model is in figure 2. Furthermore, it also provides the theoretical background of BSC, which leads to the development of the hypothesis. Sim and Koh (2001) verified the causal relationship between several indicators of individual performance among the four categories of BSC through relationships and regression analysis. A hypothesis was constructed in relating to four perspectives, against the perspective of strategic goals and sustainable competitive advantage, ultimately the main themes discussed, conclusions, managerial implications taken as a step.

$\mathrm{Wu}$ (2012) used a multiple criteria analysis tool to determine causal relationships between main performance indicators for each BSC perspective to create strategy maps visualized in a logical link to improve performance. BSC organizational strategy is represented by the connected performance via a causal relationship because $\mathrm{BSC}$ is able to look to the future / long term.

BSC model of measurement results will undertake business presence information. The model presented can be used as the basic model of measurement models in the following year to evaluate the performance of the personnel concerned and short term input events to achieve long-term strategies in accordance with the vision. Gomes et al. (2013) and Mehrdad et al. (2013), through changes in the organization, viewed the purpose and size of the BSC from four perspectives. Bhattacharya, et al (2014) stated a causal relationship involving organizational commitment and traditional financial measures. Ratnasingam (2014) made a report on a small business, the lack of financial capital and technical or managerial skills, as a strategic management system. Elaboration of the four perspectives are as follows: Financial perspective, providing financial goals need to be achieved by the organization in realizing its vision, customer perspective provides a description target market segments and customers along with demands served by the organization in an effort to target financial strategy, internal and Business Process Perspective. Giving a picture of the process that must be built to serve the customer and the Learning and Growth perspective is a booster to build the competence of personnel, information system infrastructure and atmosphere of the work environment needed. Referral approaches of (Grigoroudis at. al, 2012; Huang, 2009; Mehrdad at. al, 2013; Mendes at. al, 2012; and Ratnasingam, 2014).

\section{THE VARIABLE OF FORMULATION STRATEGY OF FOUR PERSPECTIVES OF BSC}

BSC method provides a comprehensive framework for outlining a vision into strategic goals. Comprehensive strategic objectives can be formulated since BSC method (Kaplan and Norton, 1996a) uses four perspectives: financial, customer, internal business processes, learning, and growth. The summary descriptions of the four perspectives are as follows: Financial perspective provides financial goals need to be achieved by the organization in realizing its vision. Customer perspective provides a description of targeted market segments and customers as well as their demands will be served by the organization in an effort to achieve the financial strategic objective. Internal business process perspective provides an overview process shall be built to serve customers, and Learning and Growth perspective is a booster to build the competence of personnel, infrastructure of information systems necessary and working environment atmosphere. Reference of approach are (Grigoroudis at. al, 2012; Huang, 2009), Mehrdad at. al, 2013; Mendes at. al, 2012; Ratnasingam, 2014). 


\section{FINANCIAL PERSPECTIVE}

In BSC, financial perspective consistently becomes one concern because the financial measurement was one economic consequence happened due to the decision and stable economic activity. The evaluation/measurement of financial performance showed if planning, implementation, and application as well as strategy provided some basic improvement both in gross operating income and return on investment. (As can be seen in Tabel 1) with an approach of reference (Behn at. al, 1999; Bhattacharya at. al, 2014; Grogorodius at. al, 2012; Huang, 2009; Tseng, 2010; Nielsen at. al, 2012)

\section{CUSTOMER'S PERSPECTIVE}

The benchmarks of customer's standard can be classified into two groups: core measurement group and customer's value proposition. The first group consists of market share, customer acquisition, customer retention, customer's satisfaction, and customer's profitability. Meanwhile, the proposition group is classified into 3 (three) sub-groups: production attributes (price, quality, and function), customer's relationship, image, and reputation.

Endogen variable of customer's perspective is formed by two formation variables. The first is Increasing customer's Trust. The references are (Huang, 2009; Wu, 2012; Nielsen at. al, 2012)

\section{PERSPECTIVE OF INTERNAL BUSINESS PROCESS}

Efficiency measurement and company's effectiveness in producing goods and services perspective is required to measure all activities conducted by the manager and his employees in a company in efforts to fulfill the customer's satisfaction, the owner of the company, and businessmen. Every company has its own certain series of processes in efforts to create a certain score/point for customers (Kaplan and Norton, 1996b).

Internal business process is established from two formation variables:

The first is Increasing the quality of customer's service process and The second formation variable is State of the Art Technology (Tabel-1). Reference approach: (Baggio et al, 2011; Bhattacharya et al, 2014; Huang, 2009; Wu et al, 2009; Kaplan \& Norton, 1992; Malina et al, 2001; Martinsons et al, 1999; Mehrdad et al, 2013; Tseng, 2010; Naranjo et al, 2009; Nikzadet et al, 2011; Ratnasingam, 2014; and Sabah et al, 2012).

\section{LEARNING AND GROWTH PERSPECTIVE}

Measuring the company's ability to develop and utilize human resources is required so that the company's strategic objectives could be achieved for the present and the future. Kaplan and Norton (1996b) revealed that it is important for the company to pay attention to its employees, to monitor the welfare of employees and to increase the knowledge of their employees, because with increased knowledge of employees, it would support the significant improvement of the performance of employees in achieving the company's goals (Tabel-1).

The four perspectives have a close relationship and affect each other. It also could not be separated in implementation. This is when the researcher use SEM tool so that the world of publication have different colors. Reference of approach (Bhattacharya at. al, 2014; Chen at. al, 2011; Grigoroudis at. al, 2012; Huang, 2009; Nikzad at. al, 2011).

\section{METHODOLOGY}

\section{Measurement Indicators}

Constructs/variables are measured through indicators, and most of the previous researchers used secondary data. This research used primary data, where measurement indicators written in the form of statements contained in the questionnaire were given to respondents using a scoring system from strongly agree to strongly disagree with seven (7) points (semantic scale). The tool used to manage is Amos 22 (Arbuckle, 2013) and the same measurement is done by (Lee at. al, 2009). The latent variables and indicators of measurement used in the research are shown in Table - 1 .

The research variables consist of five steps, including learning and growth, internal business processes, customer performance, financial performance, strategic goals, and excellence balanced scorecard perspective. Steps are based on the adaptation of previous researchers (Butler et al, 1997; Epstein et al, 1998; Harvey et al, 1999; Lipe et. al, 2000; Martinsons et al, 1999; Mayo, 2000; Petty et al 2000; Yawson et al, 2006) and so forth.

\section{Data Collection}

The questionnaires were distributed to 110 entrepreneurs and craftsmen who are competent at the association of shoes and sandals in Wedoro Sidoarjo as well as furniture craftsmen in Pasuruan Indonesia. However, after a rechecking process, there were only 100 questionnaires that contained complete data. Therefore, the number of samples used in this research is 100 samples. Therefore, it is necessary to the choose metrics of in-out by assuming variable formations. Internal Business Processes is to improve the quality of customer service process, State of the art technology, enhance customer trust, and speed of service. These four constructs cause multi-colinearity. Indicators of the four constructs are functioned as indicators of the internal business process. It is also done on the variable of the customer. Performing invalid variable disposal is done on empowerment and alignment indicators, Financial and Comprehensive Perspective. In this process occurs a new discovery of the combined concept which is originally a combination of one step and two steps which transformed into one step concept. Steps are based on the adaptation of the previous researchers (Waluyo, 2009).

\section{Assessment of Measurement Model}

The first step of SEM tool is to test the Measurement Model which from its results can be concluded that the dimensions used by researchers do not yet reflect the analyzed latent variables, but all indicators of value $\mathrm{CR}>\mathrm{t}$ table after discharge indicator ( $\left.\mathrm{X} 1.6, \mathrm{Y}_{4.4}\right)$, so it can be concluded that the indicators were the dimension of the latent variable formed significantly (Waluyo, 2009). The second step is

to test the structural model which from its results can be concluded that the dimensions used by researchers do not yet reflect the analyzed latent variables, as shown by test results of Goodness of Fit Indices which has not shown a great value. The next step is to modify the model so that it turns to be good, this step is next to be reference 
in arranging business strategies and tactics, this model will be used as the basic capital and benchmark for the coming year measurement. The recapitulation of model modification can be seen on the next page. A complete evaluation can be done as follows is ok:

\section{RESULTS}

Testing of research hypotheses

\section{Hipotesis One (H-1)}

Ho:The learning process does not significantly influence the internal business processes.

H1: The learning process significantly influences the internal business.

\section{Test results of $\mathrm{H} 1$ hypothesis, accepted}

The learning process (X1) significantly influences internal business processes, with a regression coefficient of .321 , the probability value $<.05(.041) \quad$ (see Table 3 ), it means that the learning process increase by 1 unit in the form of activities (employee satisfaction, employee retention, employee productivity, motivation and empowerment and alignment) which will improve internal business processes at .321. One thing to note is once employee's learning process and performance are positive, they must be maintained so that the best workers that will not leave the organization / company, the worker has to have a high artistic soul, this business line involves in the arts (shoe and furniture industry).

Table - 1. Variable and Indicator

Source: The primary data analyzed

\begin{tabular}{|c|c|c|c|}
\hline Variable & $\begin{array}{l}\text { Formed } \\
\text { Variable }\end{array}$ & Indicator & $\begin{array}{l}\text { Intervening } \\
\text { Variable }\end{array}$ \\
\hline $\begin{array}{l}\text { Strategic Object } \\
\text { tive }\left(Y_{4}\right)\end{array}$ & & $\begin{array}{l}\text { Learning \& } \\
\text { Growth }\left(\mathrm{Y}_{4.1}\right) \text {, } \\
\text { Business Process/ } \\
\text { Internal }\left(\mathrm{Y}_{4.2}\right) \\
\text { Customer }\left(Y_{4.3}\right) \\
\text { Finance }\left(\mathrm{Y}_{4.4}\right)\end{array}$ & Finance $\left(\mathrm{Y}_{3}\right)$ \\
\hline Finance $\left(\mathrm{Y}_{3}\right)$ & & $\begin{array}{l}\text { Revenue } \\
\text { Growth }\left(\mathrm{Y}_{3.1}\right) \\
\text { Reduced Cost } \\
\left(\mathrm{Y}_{3.2}\right)\end{array}$ & $\begin{array}{l}\text { Customer } \\
\left(\mathrm{Y}_{2}\right)\end{array}$ \\
\hline \multirow[t]{2}{*}{ Customer $\left(\mathrm{Y}_{2}\right)$} & $\begin{array}{l}\text { Increasing } \\
\text { Customer's } \\
\text { Trust }\left(\mathrm{Y}_{2.1}\right)\end{array}$ & $\begin{array}{l}\text { Time }\left(\mathrm{Y}_{2.1 .1}\right) \\
\text { Quality }\left(\mathrm{Y}_{2.1 .2}\right) \\
\text { Cost }\left(\mathrm{Y}_{2.1 .3}\right)\end{array}$ & $\begin{array}{l}\text { Business } \\
\text { Process/ } \\
\text { Internal }\left(\mathrm{Y}_{1}\right)\end{array}$ \\
\hline & $\begin{array}{l}\text { Speed of } \\
\text { Service }\left(Y_{2.2}\right)\end{array}$ & $\begin{array}{l}\text { Availability of } \\
\text { product images } \\
\left(\mathrm{Y}_{2.2 .1}\right) \\
\text { On time delivery } \\
\left(\mathrm{Y}_{2.2 .2}\right)\end{array}$ & \\
\hline \multirow[t]{2}{*}{$\begin{array}{l}\text { Business } \\
\text { Process/ Intern } \\
\left(\mathrm{Y}_{1}\right)\end{array}$} & $\begin{array}{l}\text { Increasing } \\
\text { the quality of } \\
\text { customer } \\
\text { service } \\
\text { process } \\
\left(Y_{1.1}\right)\end{array}$ & $\begin{array}{l}\text { Inovation Process } \\
\left(\mathrm{Y}_{1.1 .1}\right) \\
\text { Operational } \\
\text { Process }\left(\mathrm{Y}_{1.1 .2}\right) \\
\text { After Sale } \\
\text { Service Process } \\
\left(\mathrm{Y}_{1.1 .3}\right) \text {, } \\
\text { Ease of Payment } \\
\text { Process }\left(\mathrm{Y}_{1.1 .4}\right) \\
\text { Satisfying maket } \\
\text { segment through } \\
\text { product or } \\
\text { service }\left(\mathrm{Y}_{1.1 .5}\right) .\end{array}$ & \\
\hline & $\begin{array}{l}\text { Stateof the } \\
\text { art } \\
\text { technologi } \\
\left(\mathrm{Y}_{1.2}\right)\end{array}$ & $\begin{array}{l}\text { High level taste } \\
\text { of art worker } \\
\left(\mathrm{Y}_{1.2 .1}\right) \\
\text { Fast Response on } \\
\text { art technology } \\
\left(\mathrm{Y}_{1.2 .2}\right)\end{array}$ & \\
\hline
\end{tabular}

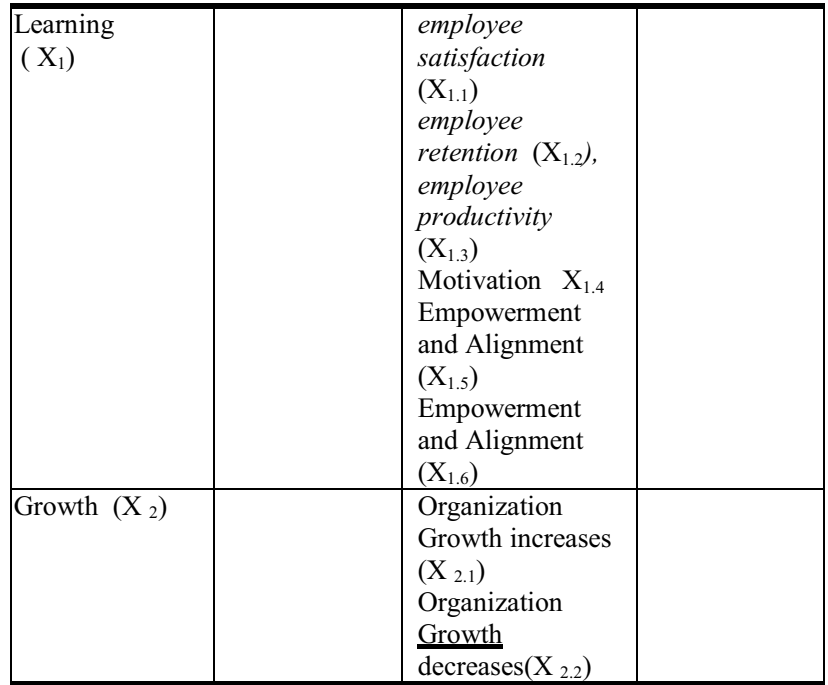

Table - 2. Goodness Of Fit and Cut Off Value (modification)

\begin{tabular}{|c|c|c|c|}
\hline $\begin{array}{c}\text { Goodness of Fit } \\
\text { Indices }\end{array}$ & $\begin{array}{c}\text { Result of } \\
\text { Model } \\
\text { Testing }\end{array}$ & $\begin{array}{c}\text { Cut }- \text { Off } \\
\text { Value }\end{array}$ & Remark \\
\hline $\mathrm{X}^{2}$ Chi Square & 276.550 & Small* & Good \\
\hline Probabilitas & 0,058 & $\geq 0,05$ & Good \\
\hline CMIN/DF & 1.150 & $\leq 2,00$ & Good \\
\hline RMSEA & 0.039 & $\leq 0,08$ & Good \\
\hline GFI & 0.836 & $\geq 0,90$ & Marginal \\
\hline AGFI & 0.811 & $\geq 0,90$ & Marginal \\
\hline TLI & 0,965 & $\geq 0,95$ & Good \\
\hline CFI & 0,972 & $\geq 0,95$ & Good \\
\hline Source: The primary data analyzed \\
\hline
\end{tabular}

Tabel - 3. Regression Weights $(\lambda)$ : (Default Model modification)

Source: The primary data analyzed

\begin{tabular}{|c|c|c|c|c|c|c|l|}
\hline $\begin{array}{c}\text { Vari } \\
\text { able }\end{array}$ & & $\begin{array}{r}\text { Esti } \\
\text { mate }\end{array}$ & S.E & C.R. & P & $(\boldsymbol{\lambda})$ \\
\hline y1 & $<--$ & x1 & -.024 & .153 & -.158 & .041 & .321 \\
\hline y1 & $<--$ & x2 & .576 & .248 & 2.326 & .020 & .327 \\
\hline y2 & $<--$ & y1 & .302 & .076 & 3.963 & .039 & .419 \\
\hline y3 & $<--$ & y2 & .046 & .156 & 2.294 & .036 & .311 \\
\hline Y4 & $<--$ & Y3 & .399 & .166 & 3.291 & $* * *$ & .275 \\
\hline
\end{tabular}

\section{Second hypothesis (H-2)}

Ho: The process of growth does not significantly affect on internal business processes.

H1: The process of growth significantly affects internal business processes.

\section{Test results of $\mathrm{H} 1$ hypothesis, accepted}

The process of growth significantly influences the internal business processes with a regression coefficient of .327 with a probability value $<.05(.020)$. In table- 3 , it means that the process of growth increased by 1 unit, in the form of growth-enhancing activities of the organization and preventing the organization from declining will improve the internal business processes at .327 . The test results support the (Bhattacharya et al, 2014; Chen at al, 2011; Geuser at al, 2009; Ken Ogat at al, 2014; Tseng, 2010; Sangjae at al, 2013; Seyed at al, 2011; Stewart, 2001). 


\section{Third (H-3) \& Fourth Hypothesis (H-4)}

Ho: Internal business processes does not significantly affect on the quality elevation of the customer service processes.

H1: Internal business processes significantly affects the elevation quality of the customer service processes, and Ho: Internal business processes does not significantly affect on state of the art technology

H1: Internal business processes significantly affects on state of the art technology

Hypothesis test results can not be proved because there is a "Warning" in which there are indications of multicolinearity. Supported by (Waluyo, 2009).

\section{Fifth Hypothesis (H-5)}

Ho: Internal business processes does not significantly affect customers.

H1: Internal business processes (Y1) significantly affects customers.

\section{Test results of $\mathrm{H1}$ hypothesis, accepted}

Internal business processes significantly influence the customer with a regression coefficient of .419 , with the probability value of $<.05$ (.039). (See Table 3 ) This means if internal business process increases by 1 unit in the form of activities to improve the coordination of all existing indicators so that it is more synergized, it will increase the number of customers amounted to .419 , resulting in products that are of high artistic quality. The test results support the (Chen, at al, 2011; Wu, 2012; Mendes, at al, 2012; Sangjae, at al, 2013).

\section{Sixth (H-6) Seventh Hypothesis (H-7)}

Ho: Customer does not significantly affect increasing customer trust.

H1: Customer significantly affects increasing customer trust, and

Ho: Customer does not significantly affect service speed.

H1: Customer significantly affects service speed.

Hypothesis test results can not be proved because there is a "Warning" in which there are indications of multicolinearity. Supported by (Waluyo, 2009).

\section{Eighth Hypothesis (H-8)}

Ho: Customer does not significantly affect finance. H1: Customer significantly affects finance.

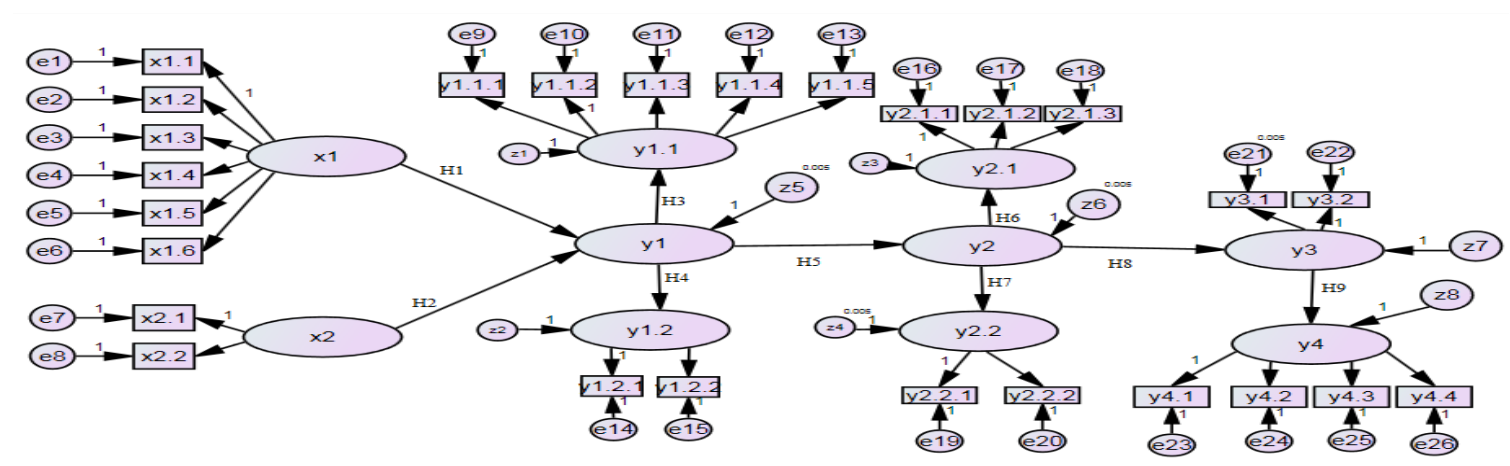

Figure-1. Research Model Hypothesis Source: The primary data analyzed

\section{Test results of $\mathrm{H} 1$ hypothesis, accepted}

Customers have a significant effect on the financial with a regression coefficient of .311 , and a probability value of $<.05(.049)$ (see table 2 ). The score .311 means that if customer increases by 1 unit in the form of negotiation activities that enhance customer trust with three indicators (on time finished order, the quality standards to order, and low cost to improve the speed of service to customers), it will increase the finance by .311 . The test results support the (Bhattacharya, at al, 2014; Chen, at al, 2011; Mendes, at al, 2012; Sangjae, at al, 2013).

\section{Ninth Hypothesis (H-9)}

Ho : Finance does not significantly affect on strategic objective perspective.

H1 : Finance significantly affects on strategic objective perspective.

\section{Test results of $\mathrm{H} 1$ hypothesis, accepted}

Finance significantly affects the strategic objective perspective with a regression coefficient of .275 and probability value of $<.05(.050)$ (see table 2 ). The score of .275 means that if finance increases by 1 unit in the form of reduction of the cost, the revenue growth will increase the strategic objective of .275 by synergizing strategic objective perspective indicator. However, since financial perspective indicator is not significant, it is disposed of. This is done because the majority of SMEs capital is independent capital. This is due to the mindset of those affected by the parental discourse that bank debt gives a headache. The test results support the (Behn, et al, 2010; Bhattacharya, et al, 2014; Grigoroudis, et al, 2012; Huang, 2009; Mehrdad, et al, 2013; Mendes, et al, 2012; Naranjo, et al, 2009; Sangjae, et al, 2013) 


\section{DISCUSSIONS}

\section{Implications for researchers}

The results of implications of model simulation are as follows: Goodness of Fit modifications $\mathrm{DF}=227$, Chisquare $=276.550, \mathrm{P}=.058, \mathrm{CMIN} / \mathrm{DF}=1.150, \mathrm{GFI}=$ $.831, \mathrm{AGFI}=.791, \mathrm{CFI}=.972, \mathrm{TLI}=.965$ and $\mathrm{RMSEA}=$ .039 , where all variables have significant and direct effect. BSC model synergized with the SEM is a model of the new discovery combined models between one step and two steps. Because the process occurs in multi-colinearity, it eventually becomes the concept of one step that is supported by (Waluyo, 2009).

\section{Implications for practitioners}

In the work pattern of sandals and furniture industry before the monetary crisis (1997-1998), there were not many players in the industry who knew about banking. In running their businesses, they used their own capital added with down payment for each order of products (slippers and furniture). By having this unique method of work, it makes the industry still exists, but obtaining a capital loan should also be considered to accelerate the process of growth when the outlook is promising. This mindset led to the process of learning and growth which significantly affects the internal business processes, customers, and finances.

Based on the primary data, through the interview of mindset and small industry players' behavior at a time of crisis in Indonesia, they had made innovations as suggested in the modified model, in which keeps them exist.

This experience is an important grip in running entrepreneurship so that Indonesia would still exist and is always ready to face the economic crisis. This also proves that the stability of economic growth in Indonesia is number one in the world in this era. In the current era, through its lecturers, universities are approaching in the implementation of its three principles of higher education, namely one of which is teaching on how to easily get a bank loan and they also oversee the process to get it. This makes SMEs grow faster.

The basic model of measurement model of BSC is a comparison measurement of BSC models in the years to come. If the result of measurement model of BSC is better, then the SMEs model exist. The measurement model of BSC model has a cause and effect relationship, through which will oversee the process to get it. This makes SMEs grow faster relationship model, a strategy which can be easily animated as well as criticized at the same time because every relationship and causality can be tested in detail. (Kaplan and Norton, 1996b).

An effective government's decision is not immune from the perspective of the BSC combining four steps focus on systems with behavior / different steps, namely by adding a strategic variable. BSC causes all variables to have a significant effect, which is supported by (Lipe and Salterio, 2000; Malina and selto, 2001; Dess and Shaw, 2001; Ittner, et al, 1998; Amado, et al; 2012, Epstein, et al, 1998; Wu, et al, 2012).

\section{CONCLUSIONS}

The BSC model in this paper was proposed to improve the original model. At the start of the three-step analysis and structural equation Measurement and modification of the model, the value of its Goodness of Fit Indices was good, although there were two values that gave test results in marginal status.

The effect of BSC variable is significant and direct the learning perspective for significant influence internal business processes with a regression coefficient of .321 and the Growth Perspective significant effect for internal business processes with a regression coefficient of .327 . The next in a chain of internal business processes are customers with a regression coefficient of .419. Customers have a significant effect for Financial with a regression coefficient of .311. A significant effect for Financial Perspective strategic objectives is with a regression coefficient of .275 , where the model of an integrated approach produced test results. The goodness of Fit Indices is good after the model was modified.

\section{REFERENCES}

Amado, C.A.F, Sérgio P. Santos, Pedro M. Marques, Integrating The Data Envelopment Analysis and The Balanced Scorecard Approaches for Enhanced Performance

Arbuckle J.L, $\quad$ IBM ${ }^{\circledR} \quad$ SPSS ${ }^{\circledR} \quad$ Amos $^{\mathrm{TM}} \quad 22, \quad$ Amos Development Corporation,2013

Baggio R, Sainaghi R. Complex and Chaotic Tourism Systems: Towards a Quantitative Approach. International Journal of Contemporary Hospitality Management, 23 (6), 2011, pp. 840-861.

Banker R.D. Chang, H. Pizzini M.J. The Balanced Scorecard: Judgemental Effects of Performance Measures Linked to Strategy. The Accounting Review 79 (1), 2004, pp 1-23.

Bhattacharya A, Priyabrata Mohapatra, Vikas Kumar, Prasanta Kumar Dey, Malcolm Brady, Manoj Kumar Tiwari \& Nudurupati Sai S, Green Supply Chain Performance Measurement Using

Butler. A, Letza, S.R, Neale, B. Linking The Balanced Scorecard to Strategy, Long Range Planning 30 (2), 1997, pp. 242-253.

Behn, B.K, Riley R.A, Using Non-Financial Information to Predict Financial Performance: The Case of The U. S. Airline Industry, Journal of Accounting, Auditing and Finance 14, 1999, pp. 29-56. Scorecard Approach, Expert Systems with Applications 37 (8), 2010, pp. 5931-5938.

Chen F-H, Hsu T-S, Tzeng G-H, A Balanced Scorecard Approach To Establish a Performance Evaluation And Relationship Model For Hot Spring Hotels Based On a Hybrid MCDM Model Combining DEMATEL and ANP, International Journal of Hospitality Management, 30 (4), 2011, pp. 908-932

Dess G.G, Shaw D.J, Voluntary Turnover, Social Capital, and Organizational Performance. The Academy of Management Review 26 (3), 2001, pp. 446-456. 
Epstein M, Manzoni J.-F, Implementing Corporate Strategy: From Tableaux De Bord to Balanced Scorecards, European Management Journal 16 (2), 1998, pp. 190-203.

Geuser, S. Mooraj F.D. \& Oyon D, Does The Balanced Scorecard Add Value Empirical Evidence on Its Effect on Performance, European Accounting Review 18(1), 2009.

Gomes J, Romao M, Mário Caldeira, The Benefits Management and Balanced Scorecard Strategy Map : How They Match 4 (1), 2013, pp. 11.

Gonzalez-Padron.T, Chabowski B, Hult G.T.M, Ketchen D.J, Knowledge Management and Balanced Scorecard Outcomes: Exploring the Importance of Interpretation, Learning and Internationality, British Journal of Management 21 (4), 2010, pp. 967-982.

Grigoroudis. E, Orfanoudaki E, Zopounidis C, Strategic Performance Measurement In a Healthcare Organisation : A multiple Criteria Approach Based on Balanced Scorecard, Omega40 (1), 2012, pp. 104-119.

Harvey M.G., Lusch F.R, Balancing the Intellectual Capital Books : Intangible Liabilities, European Management Journal 17 (1), 1999, pp. 85-92.

Huang. H-C. Designing a Knowledge-Based System for Strategic Planning : A Balanced Scorecard Perspective, Expert Systems with Applications36 (1), 2009, pp. 209218.

Ittner C.D, Larcker D.F, Are Non-Financial Measures Leading Indicators of Financial Performance? An Analysis of Customer Satisfaction Journal of Accounting Re-search Supplement 36, 1998, pp. 1-35.

Johnson H.T, Kaplan R.S, Relevance Lost, The Rise and Fall of Management Accounting. Harvard Business School Press, Boston, MA.1987

Kaplan R.S, Norton D.P, Linking the Balanced Scorecard to Strategy.California Management Review 39 (1), 1996, pp. 53-79.

Kaplan R.S, Norton R.D, Using The Balanced Scorecard As a Strategic Management System, Harvard Business Review 1996b, pp. 75-85.

Ken Ogat, Gary Spraakman, Beyond Control: Using the Balanced Scorecard to Change Culture and Implement Strategy, Canadian Academic Accounting Association (CAAA) Annual Conference 2014, pp. 1-50.

Lee S, Park, S.Y, Do Socially Responsible Activities Help Hotels and Casinos Achieve Their Financial Goals International Journal of Hospitality Management 28 (1), 2009, pp. 105-112.

Lipe M.G, Salterio S.E, The Balanced Scorecard: Judgmental Effects of Common and Unique Performance Measures, Accounting Review 75 (3), 2000, pp. 283- 298.
Malina, Selto .F, Controlling and Communicating Strategy : An Empirical Test of The Effectiveness of The Balanced Scorecard. Journal of Management Accounting Research, 2001, pp. 47-90.

Martinsons M, Davison, R, Tse. D, The Balanced Scorecard: a Foundation For The Strategic Management of Information Systems, Decision Support Systems 25 (1), 1999, pp. 25-36.

Mayo A, The Role of Employee Development in The Growth of Intellectual Capital, Personnel Review 29 (4), 2000, pp. 2000.

Mehrdad N. A, Vahid Majazi Dalfard, Kiarash Poursalik, A Combination Model Using Strategic Alignment Model and Balanced Scorecard and Strategies' Prioritisation Based on TOPSIS Technique, International Journal of Productivity and Quality Management12 (3), 2013, pp. 313-326.

Mendes P, Ana Carina Santos, Fernando Perna, Margarida Ribau Teixeira, The Balanced Scorecard as an Integrated Model Applied to The Portuguese Public Service: a Case Study in The Waste Sector Journal of Cleaner Production24, 2012, pp. 20-29.

Naranjo-Gil, David, Strategic Performance in Hospitals: The Use of The Balanced Scorecard by Nurse Managers, Health Care Management 34 (2), 2009, pp. 161-170.

Nielsen S, Nielsen E.H, Discussing feedback System Thinking in Relation to Scenario Evaluation in A balanced Scorecard Setup, Production Planning \& Control 23 (6), 2012, pp. 436-451.

Nikzad Manteghi, Abazar Zohrabi, A Proposed Comprehensive Framework for Formulating Strategy: a Hybrid of Balanced Scorecard, SWOT Analysis, Porter's Generic Strategies and Fuzzy Quality Function Deployment. Procedia - Social and Behavioral Sciences, 15, 2011, pp. 2068-2073.

Petty R, Guthrie J, Intellectual Capital Literature Review: Measurement, Reporting, and Management, Journal of Intellectual Capital 1 (July (2)), 2000, pp. 155-176.

Ratnasingam P, The Evolution of Balance Scorecard and its Impact on Web Services Quality, International Journal of Organizational and Collective Intelligence (IJOCI) 4 (1), 2014, pp. 12.

Sabah M. Al-Najjar, Khawla H. Kalaf, Designing a Balanced Scorecard to Measure a Bank's Performance : A Case Study, International Journal of Business Administration 3 (4), (2012), pp. 44.

Sangjae. Lee, Sung Bum Park, Gyoo Gun Lim, Using Balanced Scorecards For the Evauation of "Software-as-aService” Information \& Management, 2013, pp. 553-561.

Seyed Mohammad Seyedhosseini, Ahmad Ebrahimi Taleghani, Arash Bakhsha, Solmaz Partovi Extracting Leanness Criteria by Employing the Concept of Balanced 
Scorecard, Expert Systems with Applications 38 (8), 2011, pp 10454-10461.

Sim K.L, Koh H.C, Balanced scorecard: A Rising Trend in Strategic Performance Measurement, Measuring Business Excellence 5, 2001, pp.18-27.

Stewart W.E., Balanced Scorecard for Projects, Project Management Journal 32 (1), 2001, pp. 38-53.

Taylor J, Baines C, Performance Management in UK Universities: Implementing the Balanced Scorecard, Journal of Higher Education Policy \& Management 34 (2), 2012, pp. 111-124.

Tobia, R.D. An Introduction to Least Squares Regression, SAS Institution Inc, 1999.

Tseng. M-L, Implementation and Performance Evaluation Using The Fuzzy Network Balanced Scorecard, Computers \& Education55 (1), 2010, pp. 188-201.
Waluyo. M, Object and Applied Structural Equation Modelling, PT. Indeks, 2009, Jakarta.

Wu H.Y, Constructing a Strategy Map for Banking Institutions With Key Performance Indicators of the Balanced Scorecard, Evaluation \& Program Planning 35 (3), 2012, pp. 303-320.

Yawson R, Amoa-Awua W, Sutherland A, Smith D, Noamesi S, Developing a Performance Measurement Framework to Enhance the Impact Orientation of the Food Research Institute, Ghana, R\&D Management 36 (2), 2006, pp. 161- 172 .

Zahirul Hoque, 20 Years of Studies on the Balanced Scorecard: Trends, Accomplishments, Gaps and Opportunities for Future Research, The British Accounting Review46, (1), 2014, pp. 33-59. 